Journal of Anatolian Environmental and Animal Sciences

(Anadolu Çevre ve Hayvancllık Bilimleri Dergisi)

DOI: https://doi.org/10.35229/jaes.832315
Year: 6, No: 1, $2021(66-71)$

AÇEH

Y1l: 6, Say1: 1, $2021(66-71)$

\title{
Comparative Genomics Insight into Phytopathogenic Xanthomonas arboricola pathovar corylina Strains
}

\author{
Safak KALINDAMAR \\ Department of Molecular Biology and Genetics, Faculty of Arts and Sciences, Ordu University, 52200, Ordu, Turkey
}

How to cite: Kalındamar, Ş. (2021). Comparative genomics insight into phytopathogenic Xanthomonas arboricola pathovar corylina strains. J. Anatolian Env. and Anim. Sciences, 6(1), 66-71.

Atıf yapmak için: Kalındamar, Ş. (2021). Fitopatojenik Xanthomonas arboricola patovar corylina suşlarına karşılaştırmalı genomik bakış. Anadolu Çev. ve Hay. Dergisi, 6(1), 66-71.

\section{: https://orcid.org/0000-0003-2897-9911}

*Corresponding author's: Şafak KALINDAMAR

Department of Molecular Biology and

Genetics, Faculty of Arts and Sciences, Ordu

University, 52200, Ordu, Turkey.

凶: safakkalindamar@odu.edu.tr
Abstract: Xanthomonas arboricola pathovar corylina (Xac) causes a bacterial blight disease (BBD) resulting in economic losses in young hazelnut trees worldwide. Although virulent Xac genomes were sequenced, there is no comparative genomics study on these genomes. In this study, all publicly available whole-genome sequences of Xac were compared by a comparative genomics approach. The results showed that Xac CFBP1159 and Xac CFBP2565 genomes are phylogenetically related to each other based on the orthology results. The genomic diversification of Xac strains was depended on mobile genetic elements. Interestingly, Xac NCCB100457 genome had additional motility genes than Xac CFBP1159 and Xac CFBP2565 genomes. All Xac genomes had shared virulence-related genes such as secretion systems and adherence factors. The comparative genomics approach of this study supports that Xac genomes have slight genetic variations, and the virulence-related proteins interacted with the host proteins. This comparative genomics approach will provide insights into the understanding of the Xac genomes.

Keywords: Comparative genomics, host-pathogen interaction, phytopathogenic, virulence, Xanthomonas.

\section{Fitopatojenik Xanthomonas arboricola patovar corylina Suşlarına Karşılaştırmalı Genomik Bakış}

\section{*Sorumlu yazar:}

Safak KALINDAMAR

Ordu Üniversitesi, Fen-Edebiyat Fakültesi,

Moleküler Biyoloji ve Genetik Bölümü,

52200 , Ordu, Türkiye.

\: safakkalindamar@odu.edu.tr
Öz: Xanthomonas arboricola patovar corylina (Xac), Dünya çapında genç findık ağaçlarında ekonomik kayıplarla sonuçlanan findık bakteriyel yanıklığı hastalığına neden olmaktadır. Virülent Xac suşlarının tüm genomları dizilenmiş olmasına rağmen, bu genomlar üzerinde bir karşılaştırmalı genomik çalışma yoktur. Bu çalışmada, Xac suşlarının halka açık tüm genom dizileri, karşılaştırmalı genomik yaklaşım kullanılarak karşılaştırılmıştır. Elde edilen sonuçlarda, Xac CFBP1159 ve Xac CFBP2565 genomlarının, ortoloji sonucuna göre filogenetik olarak birbirleriyle daha yakın ilişkili olduğu saptanmıştır. Xac suşlarının genomik çeşitliliğinin mobil genetik elementlerle ilişkişi olduğu anlaşılmıştır. İlginç bir şekilde, Xac NCCB100457 genomu, Xac CFBP1159 ve Xac CFBP2565 genomlarından daha fazla motilite genlerine sahiptir. Tüm Xac genomları, sekresyon sistemleri ve adhezyon faktörleri gibi virülans ile ilgili ortak genlere sahiptir. Bu çalışmanın karşılaştırmalı genomik yaklaşımı, Xac genomlarının bazı genetik varyasyonlara sahip olduğu ve virülans ile ilgili proteinlerin konakçı proteinlerle etkileşime girdiğini desteklemektedir. Bu çalışmanın karşılaştırmalı genomik yaklaşımı, Xac genomlarının anlaşılması için bir öngörü sağlamıştır.

Anahtar kelimeler: Bitki patojeni, karșılaștırmalı genomik, konak patojen ilișkisi, virülans, Xanthomonas. 


\section{INTRODUCTION}

Xanthomonas arboricola is primarily known as a Gram-negative phytopathogenic bacterium that can infect economically important plant species such as prunus, walnut, and hazelnut (Vauterin et al., 1995). X. arboricola pathovar-assigned strains are mostly described as pathogenic bacteria although there are $X$. arboricola strains considered non-pathogenic bacteria. Moreover, there are nine pathovar strains (arracaciae, celebensis, corylina, fragariae, guizotiae, juglandis, populi, pruni, and zantesdeschiae) identified in X. arboricola (Fischer-Le Saux et al., 2015). As one of the most virulent pathovars, Xanthomonas arboricola pathovar corylina $(\mathrm{Xac})$ is a causative agent of BBD of hazelnut trees (Corylus spp.). The BBD was first described on C. maxima in the USA (Barss, 1913). Later, the disease has been increasingly reported on $C$. avellana from hazelnut producer countries in the European Union (Eppo, 2004). Xac has been also prevalently isolated from the hazelnut orchards in the Black Sea Region of Turkey, which is a major hazelnut producer in Europe (Karahan et al., 2013). The symptoms of BBD can appear on hazelnut tree's leaves and twigs. It has been also reported that the disease can also kill hazelnut trees or delay the growth of trees (Lamichhane et al., 2014).

The genus of Xanthomonas include a variety of plant pathogenic bacterial species, and these bacteria can utilize diverse virulence mechanisms such as secretion systems, effector proteins of diverse secretion systems, flagella, and small RNAs (Timilsina et al., 2020). Recently, a comparative genomics study on virulent and non-virulent Xanthomonas arboricola pv. pruni (Xap) strains showed genomic differences between virulent and non-virulent Xap strains (Garita et al., 2017). On the other hand, the Xac strain was isolated from the leaf spots of $C$. colurna L. in Colorado, and the first DNA sequence of Xac was revealed in 2013 (Caballero et al., 2013). There are also sequences of two Xac genomes (Xac CFBP1159 and Xac CFBP2565) publicly stored in the National Center for Biotechnology Information (NCBI). However, these genomes were not used for any comparative genomics analysis.

Although several Xac genomes have been sequenced and their genomes were publicly available, there is no comparative genomics study on Xac's genomes. Thus, the goal of this study was to compare Xac genomes that are publicly available in the NCBI database. This study provides a comparative insight into the comparison of Xac genomes, genomic variations, orthologous clusters at the protein level, annotation and gene predictions, prediction of virulence factors, and interactions of host-pathogen proteins.

\section{MATERIAL AND METHOD}

Bacterial genome data: The Xac genomes data were obtained from NCBI (as of 01/11/2020). The Xac genomes were listed with features in Table 1.

Table 1. Genome features of Xac strains.

\begin{tabular}{|c|c|c|c|c|c|c|c|c|}
\hline Species & Strain & Host & Location & Size (Mbp) & $\mathbf{G + C}$ & Level & Accession \# & Reference \\
\hline$X a c$ & CFBP2565 & C. avellana & France & 5.05 & 65.6 & Contig & NZ_MDSJ01000001.1 & INRA \\
\hline$X a c$ & CFBP1159 & C. maxima & USA & 5.11 & 65.5 & Scaffold & NZ_MDEA01000001.1 & INRA \\
\hline$X a c$ & NCCB 100457 & C. colurna & USA & 5.23 & 65.5 & Contig & NZ_APMC02000173.1 & Caballero et al., 2013 \\
\hline
\end{tabular}

Comparative genome analyses: Blast Ring Image Generator (BRIG) was used to visualize the comparative genome analysis of Xac strains (Alikhan et al., 2011). The orthologous clusters of $\mathrm{Xac}$ strains at the protein level were calculated by using OrthoVenn2 (Wang et al., 2015). Prokaryotic Genomes Automatic Annotation Pipeline (NCBI PGAAP) and Rapid Annotation using Subsystem Technology (RAST) annotation pipelines were used for the annotation and gene prediction of bacterial genomes (Angiuoli et al., 2008; Overbeek, 2014). The potential protein-protein interactions between 3 of Xac whole proteins and the complete proteins of the eukaryotic host $C$. avellana (European hazelnut) genome (GenBank accession \#: CAAJGP010000000) were determined using the HostPathogen Interaction Database (HPIDB) by the default upload options (Ammari et al., 2016; Kumar and Nanduri, 2010). The predicted putative virulence factors were determined by downloading the full dataset from the
Virulence Factors Database (VFDB) and by uploading them to BioEdit software (Lihong et al., 2016). The local BLAST feature of BioEdit was used with a cutoff E-value of $10^{-50}$ (Hall, 1999).

\section{RESULTS}

Genome features of Xac genomes: The genomic information about Xac genomes (plant host, location, and genome-level) was summarized in Table 1. The three genomes of Xac was represented and stored in NCBI. The average genome size of $\mathrm{Xac}$ genomes is 5.13 million basepairs (Mbp). The average $\mathrm{G}+\mathrm{C}$ content of Xac genomes is $65.53 \mathrm{~mol} \%$. The NCBI genome data indicated that Xac genomes were isolated from different hazelnut species (Table 1). There are no plasmids sequences reported for Xac strains. 
Comparative analyses of Xac genomes: The visualization of the comparison of genes by BRIG showed that most of the genes among all Xac genomes were conserved (Fig 1). In orthology analysis, the comparison of proteins encoded by $\mathrm{Xac}$ genomes was determined by OrthoVenn2 (Fig 2). All strains shared 3694 clusters of orthologous proteins. The unique protein clusters identified such as 1 cluster (Non-ribosomal peptide synthetase) in Xac CFBP1159, 5 clusters (Phage portal protein, P-type conjugative transfer protein TrbJ, DDE-type integrase/transposase) in Xac CFBP2565, and 5 clusters (SDR family oxidoreductase, UvrD helicase, virulence RhuM family protein, transcriptional regulator) in Xac NCCB100457 was unique to genomes. The annotation and categorization of genes based upon the RAST showed that there is a close relationship between Xac CFBP1159 and Xac CFBP2565 genomes in the subsystems categorization of genes (Fig 3). However, Xac NCCB100457 had slightly more genes in some subcategories compared to other $\mathrm{Xac}$ genomes. Interestingly, Xac NCCB100457 had motility and chemotaxis genes, which other Xac genomes do not encode any of these genes (Fig 3). In host-pathogen interactions (HPIs), the interactions were predicted between a total of 26 proteins of Xac and 34 proteins of C. avellana (Fig 4). The virulence factors detected in $\mathrm{Xac}$ genomes were categorized based on the function such as adherence, adhesion, and secretion systems (Table 2). The pathogen proteins interacted with the host proteins are listed in Table 3.

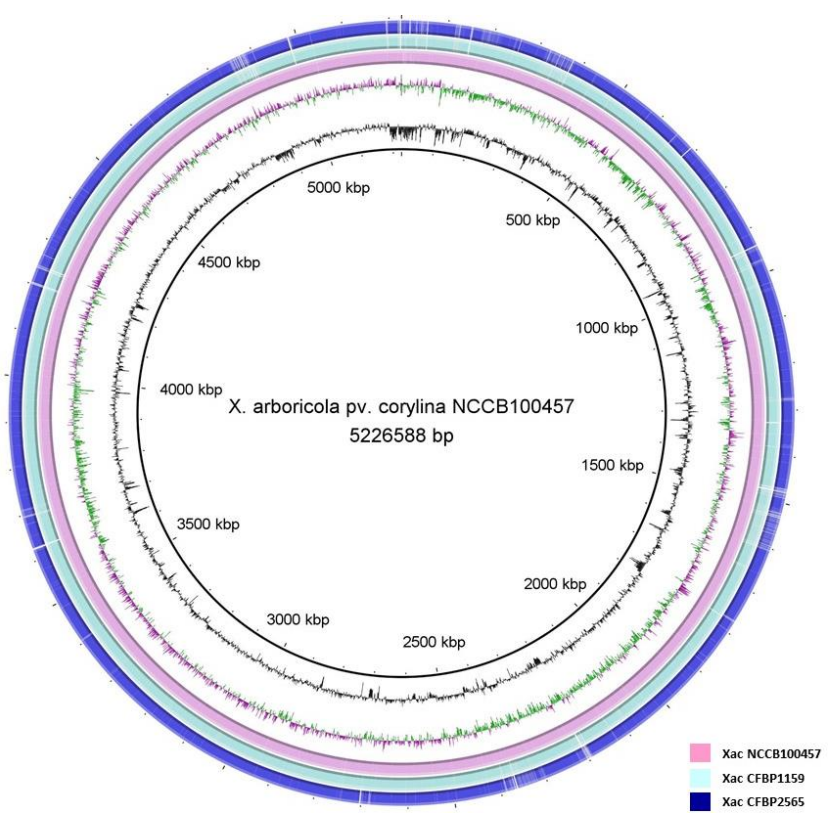

Figure 1. Comparative circular visualization of Xac genomes. The reference strain is Xac NCCB 100457. The two inner rings represent the $\mathrm{G}+\mathrm{C}$ content (black) and GC-skew (green/purple). The three outside rings represent a genomics comparison between Xac CFBP1159 and Xac CFBP2565 strains and the reference Xac NCCB100457 strain.
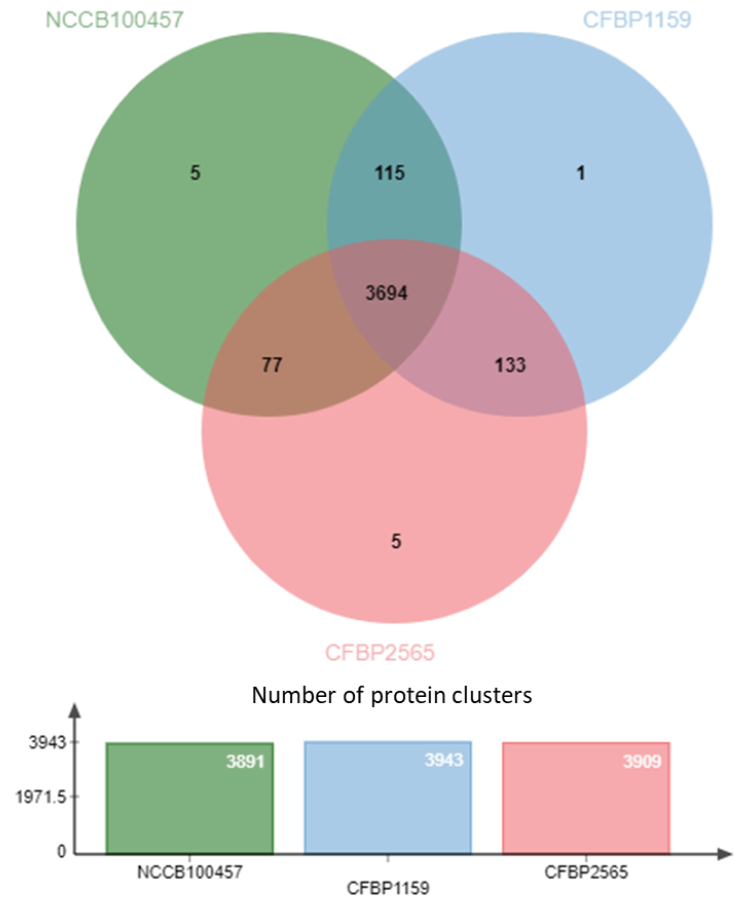

Clusters shared between Xanthomonas arboricola pv. corylina genomes

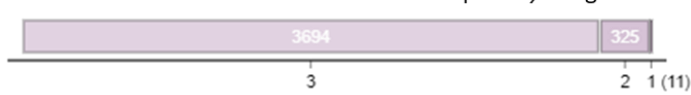

Figure 2. Venn diagram of protein clusters encoded by Xac genomes based on orthology. The Venn diagrams and bar charts show the numbers of unique and shared orthologous genes of each genome.

Table 2. Virulence factors of Xac strains.

\begin{tabular}{llccc}
\hline \multirow{2}{*}{ Class } & \multirow{2}{*}{ Virulence Factor } & \multicolumn{3}{c}{ Xanthomonas arboricola pv. corylina } \\
\cline { 3 - 5 } & & CFP1 & CFBP2565 & NCCB100457 \\
\hline Adherence & Type IV pili & $\mathbf{1 5 9}$ & & + \\
Adhesion & Outer membrane protein & + & + & + \\
Adhesion & Autotransporter-like protein & + & + & + \\
Secretion system & Type II secretion system & + & + & + \\
Secretion system & Type III secretion system & + & + & + \\
\hline (+): Presence of virulence factor in the genome. & & & \\
\hline
\end{tabular}

Table 3 Predicted pathogen proteins in host-pathogen interactions.

\begin{tabular}{lll}
\hline Species & Protein ID & Pathogen Protein \\
\hline Xac CFBP1159 & WP_016903631.1 & Diaminopimelate epimerase \\
& WP_024937682.1 & ParA family protein \\
& WP_039815062.1 & $\begin{array}{l}\text { tRNA preQ1(34) S-adenosylmethionine } \\
\text { ribosyltransferase-isomerase }\end{array}$ \\
& WP_039815650.1 & Response regulator \\
& WP_039815715.1 & Histidinol dehydrogenase \\
& WP_039816713.1 & ParA family protein \\
& WP_053045317.1 & Thioredoxin TrxC \\
& WP_053046172.1 & Mannitol dehydrogenase family protein \\
& WP_104613287.1 & CHASE3 domain-containing protein \\
Xac CFBP2565 & WP_016903631.1 & Diaminopimelate epimerase \\
& WP_024937682.1 & ParA family protein \\
& WP_039815715.1 & Histidinol dehydrogenase \\
& WP_039816713.1 & ParA family protein \\
& WP_053045317.1 & Thioredoxin TrxC \\
WP_053046172.1 & Mannitol dehydrogenase family protein \\
& WP_104566950.1 & CHASE3 domain-containing protein \\
WP_104567625.1 & Response regulator \\
Xac NCCB100457_024937682.1 & ParA family protein \\
& WP_039810077.1 & Thioredoxin TrxC \\
& WP_039810822.1 & CHASE3 domain-containing protein \\
WP_039811254.1 & Diaminopimelate epimerase \\
WP_039815062.1 & tRNA preQ1(34) S-adenosylmethionine \\
& ribosyltransferase-isomerase \\
& WP_039815650.1 & Response regulator \\
WP_039815715.1 & Histidinol dehydrogenase \\
WP_039816312.1 & Mannitol dehydrogenase, partial \\
WP_039816713.1 & ParA family protein \\
\hline Xanthomonas arboricola pathovar corylina
\end{tabular}

Xac: Xanthomonas arboricola pathovar corylina. 


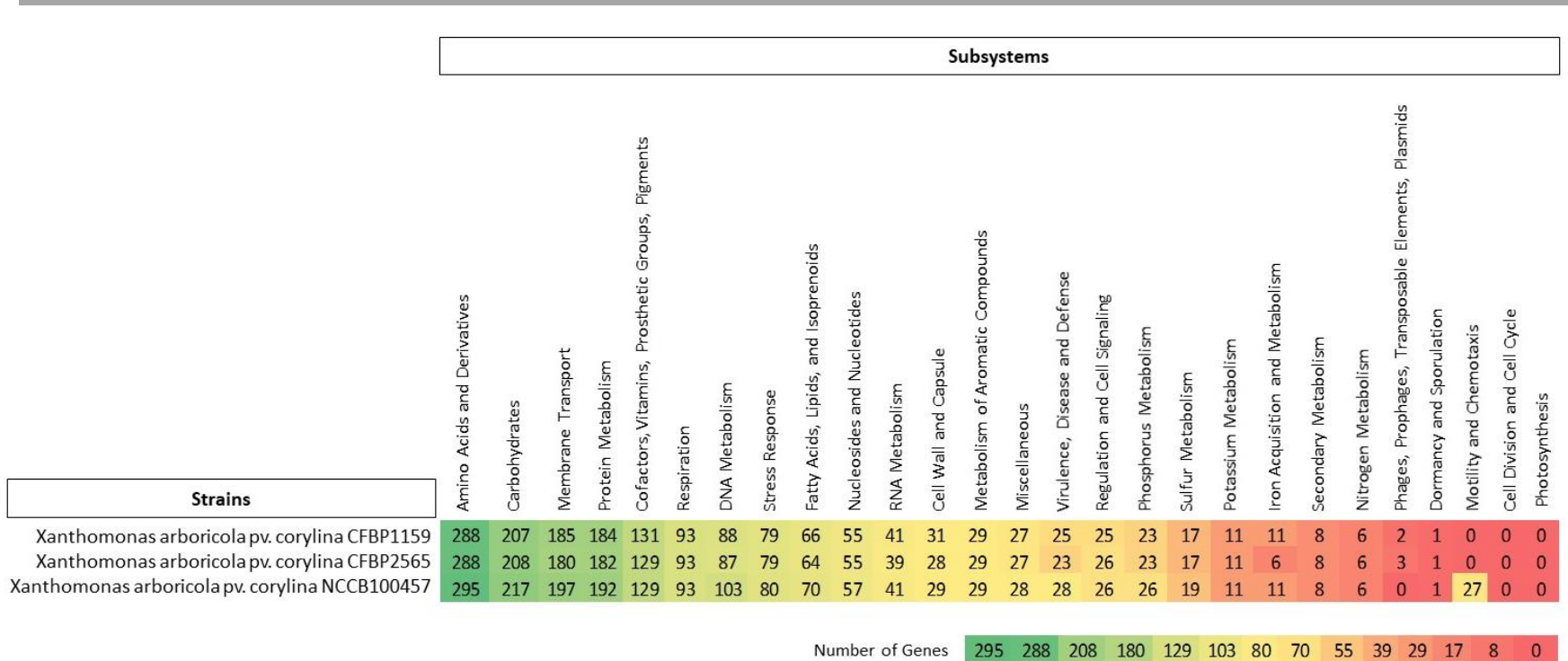

Figure 3. SEED subsystem categorization and RAST annotation of Xac genomes. The colors indicate the number of functional categorization of genes in Xac genomes.

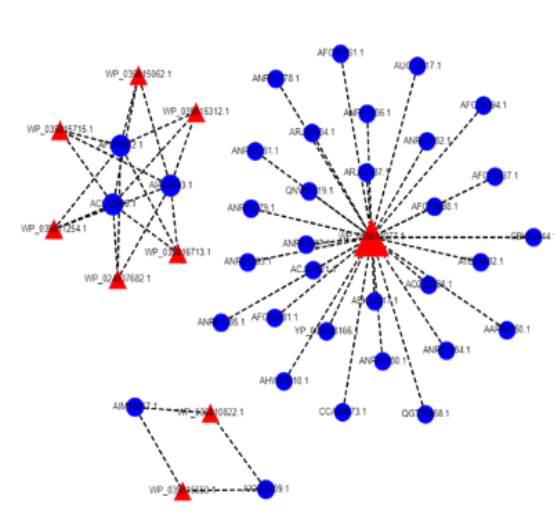

Xanthomonas arboricola pv. corylina NCCB100457

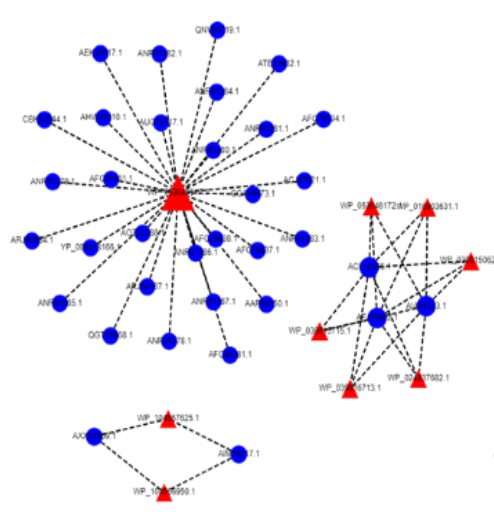

Xanthomonas arboricola pv. corylina CFBP2565

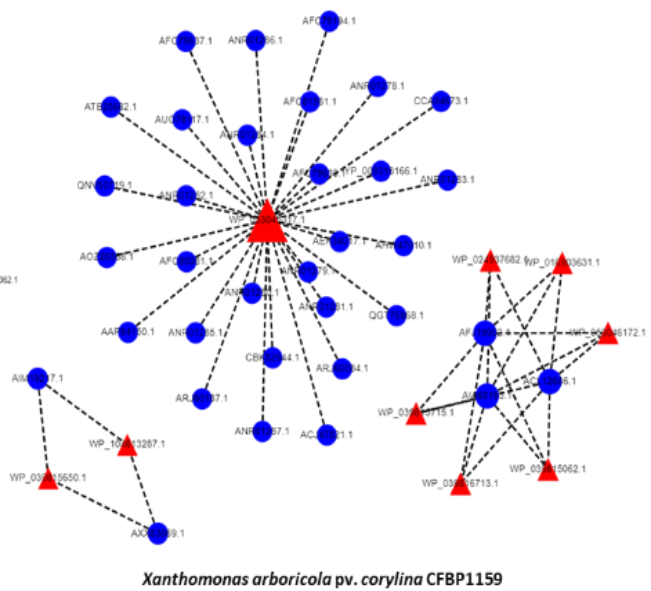

Xanthomonas arboricola pv. corylina CFBP1159

Figure 4. Visualization of predicted interactions network of host C. avellana proteins and bacterial Xac proteins. The shapes and colors represent host proteins (blues circles) and bacterial proteins (red triangles).

\section{DISCUSSION AND CONCLUSION}

In this research, all publicly available genomes of $X a c$ were analyzed by comparative genomics methods. This is the first comparative genomics analysis of Xac genomes isolated from three different hazelnut species.

Orthology analysis provides more accurate information about the phylogenetic relationship between closely related bacterial strains (Ullah et al., 2015). Based on the orthology analysis of Xac genomes in this study, Xac CFBP1159 and Xac CFBP2565 genomes are more closely related than Xac NCCB100457 genome. On the other hand, Xac strains share 3694 orthologous clusters. The genetic differences among genomes depend on mobile elements. This finding suggests that genetic differentiation of Xac genomes is linked to the acquisition of different mobile elements. Interestingly, Xac NCCB100457 genome possesses additional motility and chemotaxis gene sets.
This variation may be related to location and host adaptation.

The prediction of potential interactions between host and pathogen proteins may provide valuable information about an infection process (Durmus et al., 2015). The HPIs analysis in this study showed that a total of 26 proteins of $X a c$ proteins interacted with host $C$. avellana proteins. These results confirm that multiple potential interactions occur between $X a c$ and $C$. avellana in the host-pathogen interactions. Thus, the HPIs result demonstrated evidence of Xac virulence during infection. Determination of virulence factors of bacterial pathogens is important to understand the pathogenesis of bacteria during the infection process (Wu et al., 2008). The wholegenome sequencing of Xac strains enables identifying virulence-related factors. Identification of virulence factors in this study revealed that Xac genomes have important virulence-related factors such as type II secretion system (T2SS), type III secretion system (T3SS), and adhesion 
factors (Table 2). The bacterial adhesion of Xanthomonas strains is crucially important for the invasion of plant tissue during the diseases process (Mhedbi-Hajri et al., 2011). While $X a c$ strains invade plant tissues, degradative enzymes and secretion system-dependent effector proteins play a major role in establishing a successful bacterial infection. For example, T3SS and effector proteins are identified as important virulence factors in plant immunity suppression by Xac strains (Hajri et al., 2011; Jacques et al., 2016). In addition to T3SS, T2SS also plays an important role in secreting a variety of degradation enzymes in the genus of Xanthomonas (Szczesny et al., 2010). Overall, these virulence factors may contribute to the bacterial pathogenicity of Xac strains in the host.

As a result, the comparative genomics data presented in this study showed that Xac strains are closely related to each other. The virulence-related factors of Xac strains are also important in host-pathogen interactions.

\section{ACKNOWLEDGEMENTS}

This work was supported by the Department of Molecular Biology and Genetics, Faculty of Arts and Sciences, Ordu University, Turkey.

\section{REFERENCES}

Alikhan, N.F., Petty, N.K., Ben Zakour, N.L. \& Beatson, S.A. (2011). Blast ring image generator (BRIG): simple prokaryote genome comparisons. BMC Genomics, 12, 402.

Ammari, M.G., Gresham, C.R., McCarthy, F.M. \& Nanduri，B. (2016). HPIDB 2.0: a curated database for host-pathogen interactions. Database, (Oxford), 2016, baw103.

Angiuoli, S.V., Gussman, A., Klimke, W., Cochrane, G., Field, D., Garrity, G., Kodira, C.D., Kyrpides, N., Madupu, R., Markowitz, V., Tatusova, T., Thomson, N. \& White, O. (2008). Toward an online repository of Standard Operating Procedures (SOPs) for (meta) genomic annotation. OMICS, 12, 137-141.

Barss, H.P. (1913). A new filbert disease in Oregon. Oregon Agricultural Experiment Station Biennial Crop Pest and Horticulture Report, 14, 213-23.

Caballero, J.I., Zerillo, M.M., Snelling, J., Boucher, C. \& Tisserat, N. (2013). Genome sequence of Xanthomonas arboricola pv. corylina, isolated from Turkish Filbert in Colorado. Genome Announcement, 1(3), e00246-13. DOI: 10.1128/genomeA.00246-13

Durmus, S., Cakir, T., Ozgur, A. \& Guthke, R. (2015). A review on computational systems biology of pathogen-host interactions. Frontiers in $\begin{array}{llll}\text { Microbiology, } & \mathbf{6}, & 235 . & \text { DOI: }\end{array}$ 10.3389/fmicb.2015.00235
EPPO. 2004. (2004). Diagnosis protocols for regulated pests Xanthomonas arboricola pv. corylina. EPPO Bulletin, 34, 155-7.

Fischer-Le Saux, M., Bonneau, S., Essakhi, S., Manceau, C. \& Jacques, M.A.A. (2015). Aggressive emerging pathovars of Xanthomonas arboricola represent widespread epidemic clones distinct from poorly pathogenic strains, as revealed by multilocus sequence typing. Applied Environmental Microbiology, 81, 4651-4668. https://doi.org/10.1128/AEM.00050-15

Garita, C.J., Palacio-Bielsa, A., López, M.M. \& Cubero, J. (2017). Pan-Genomic analysis permits differentiation of virulent and non-virulent Strains of Xanthomonas arboricola that Cohabit Prunus spp. and elucidate bacterial virulence factors. Frontiers in Microbiology, 8, 573. DOI: 10.3389/fmicb.2017.00573

Hajri, A., Pothier, J.F., Saux, M.F.L. Bonneau, S., Poussier, S., Boureau, T., Duffy, B. \& Manceau, C. (2011). Type three effector gene distribution and sequence analysis provide new insights into the pathogenicity of plant-pathogenic Xanthomonas arboricola. Applied and Environmental Microbiology, 78(2), 371-384. DOI: 10.1128/AEM.06119-11

Hall, T.A. (1999). BioEdit: a user-friendly biological sequence alignment editor and analysis program for Windows 95/98/NT. Nucleic Acids Symposium Series, 41, 95-98.

Jacques, M.A., Arlat, M., Boulanger, A., Boureau, T., Carrère, S., Cesbron, S., Chen, N.W., Cociancich, S., Darrasse, A., Denancé, N., Fischer-Le Saux, M., Gagnevin, L., Koebnik, R., Lauber, E., Noël, L.D., Pieretti, I., Portier, P., Pruvost, O., Rieux, A., Robène, I., Royer, M., Szurek, B., Verdier, V. \& Vernière, C. (2016). Using Ecology, Physiology, and Genomics to Understand Host Specificity in Xanthomonas. Annual Reviews Phytopathology, 4(54), 163-87. DOI: 10.1146/annurev-phyto080615-100147

Karahan, A., Altundağ, Ş., Duran, H. \& Kılınç, A.O. (2013). Karadeniz Bölgesinde findık bakteriyel yanıklığı [Xanthomonas arboricola pv. corylina (Miller et al.) Vauterin et al.] hastalığının yaygınlığı üzerine araștırmalar. Bitki Koruma Bülteni, 53(3), 159-174.

Kumar, R. \& Nanduri, B. (2010). HPIDB - a unified resource for host-pathogen interactions. $B M C$ Bioinformatics, 11(6), S16. DOI: 10.1186/14712105-11-S6-S16

Lamichhane, J.R. \& Varvaro, L. (2014). Xanthomonas arboricola disease of hazelnut: current status and future perspectives for its management. Plant Pathology, 63(2), 243-254. DOI: 10.1111/ppa.12152

Lihong, C., Dandan, Z., Bo, L., Jian, Y. \& Qi, J. (2016). VFDB 2016: hierarchical and refined dataset for big data analysis-10 years on. Nucleic Acids 
Research, 44, D694-D697. DOI:

10.1093/nar/gkv1239

Mhedbi-Hajri, N., Darrasse, A., Pigne, S., Durand, K., Fouteau, S., Barbe, V., Manceau, C., Lemaire, C. \& Jacques, M.A. (2011). Sensing and adhesion are adaptive functions in the plant pathogenic xanthomonads. BMC Evolutionary Biology, 11, 67.

Overbeek, R., Olson, R., Pusch, G.D., Olsen, G.J., Davis, J.J., Disz, T., Edwards, R.A., Gerdes, S., Parrello, B., Shukla, M., Vonstein, V., Wattam, A.R., Xia, F. \& Stevens, R. (2014). The SEED and the Rapid Annotation of microbial genomes using Subsystems Technology (RAST). Nucleic Acids Research, 42, D206-D214. DOI: 10.1093/nar/gkt1226

Szczesny, R., Jordan, M., Schramm, C., Schulz, S., Cogez, V., Bonas, U. \& Büttner, D. (2010). Functional characterization of the Xcs and Xps type II secretion systems from the plant pathogenic bacterium Xanthomonas campestris pv vesicatoria. New Phytologist, 187(4), 9831002. DOI: $10.1111 /$ j.1469-8137.2010.03312.x

Timilsina, S., Potnis, N., Newberry, E.A., Liyanapathiranage, P., Iruegas-Bocardo, F., White, F.F., Goss, M.M. \& Jones, J.B. (2020). Xanthomonas diversity, virulence and plantpathogen interactions. Nature Reviews Microbiology, 18, 415-427.

Ullah, I., Sjöstrand, J., Andersson, P. \& Sennblad, B. (2015). Integrating sequence evolution into probabilistic orthology analysis. Systematic Biology, 64(6), 969-982. DOI: 10.1093/sysbio/syv044

Vauterin, L., Hoste, B., Kersters, K. \& Swings, J. (1995). Reclassification of Xanthomonas. International Journal of Systematic and Evolutionary Microbiology, 45(3), 472-489. DOI: 10.1099/00207713-45-3-472

Wang, Y., Coleman-Derr, D., Chen, G. \& Gu, Y.Q. (2015). OrthoVenn: a web server for genome wide comparison and annotation of orthologous clusters across multiple species. Nucleic Acids Research, 43, W78-W84. DOI: 10.1093/nar/gkv487

Wu, H.J., Wang, A.H.J. \& Jennings, M.P. (2008). Discovery of virulence factors of pathogenic bacteria. Current Opinion in Chemical Biology, 12(1), 93-101. DOI: 10.1016/j.cbpa.2008.01.023 